\title{
MNEMONIC DEVICE (KALENDER) UNTUK PENGAYAAN LITERASI MUSIM MENUJU SUMBA BARAT DAYA YANG BERDAULAT PANGAN
}

\author{
Paschalis Maria Laksono ${ }^{1}$, Wisma Nugraha Christianto $\mathbf{R}^{2}$, Arif Wahyu Widada ${ }^{3}$, Esti \\ Anantasari $^{4^{*}}$, Inda Marlina ${ }^{5}$, Olga Aurora Nandiswara ${ }^{6}$, Natasha Devanand Dhanwani ${ }^{7}$ \\ Fakultas Ilmu Budaya, Universitas Gadjah Mada, Indonesia ${ }^{12}$ \\ Fakultas Pertanian, Universitas Gadjah Mada, Indonesia ${ }^{3}$ \\ Pusat Studi Asia Pasifik, Universitas Gadjah Mada, Indonesia ${ }^{4567}$ \\ Laksono@ugm.ac.id ${ }^{1}$, krisnugraha@ugm.ac.id², arif.e.widada@ugm.ac.id ${ }^{3}$, \\ esti.anantasari@ugm.ac.id ${ }^{4 *}$, marlinainda@gmail.com ${ }^{5}$, olga.aurora@mail.ugm.ac.id ${ }^{6}$, \\ natunatasha513@gmail.com ${ }^{7}$
}

\begin{abstract}
Food sovereignty is a solution to hunger. However, in Southwest Sumba hunger is inextricably intertwined with the changes in the natural, social-economic, and cultural conditions. The food supply and also its adequacy are imagined within linked toward the needs of social contracts in the local community, namely with morality that is displayed through a series of some life cycle rituals every year. Traditionally this intertwine has been anticipated by the use of a variety of media, one of which is the seasonal calendar-- that in Southwest Sumba and many other places have been neglected. In answering this problem, this article then presents the application of a seasonal calendar, i.e., a mnemonic device that can help farmers to re-identify the spirit of nature so that farmers can farm their crops in an accordant with the cycle of nature. The seasonal calendar has been a tool for recording obscure natural signs. According to that, farmers will be able to balance between the interests of fulfilling commodities and their daily needs. By using participatory methods, this research that has been conducted for three years periods resulted: problems identification in the first year; a food sovereignty model formulation in the second year; and an enrichment of the model through a series of workshops in the third year. This article then reviews specifically on how the food sovereignty model in the form of a mnemonic device is enriched through a series of workshops, that were attended by stakeholders both in Southwest Sumba and Yogyakarta. This enrichment process was expected to facilitate and expand the accessibility of its users across gender, age, and social strata. The appreciation of the seasonal calendar will ensure that farmers are conscientious of the importance of prioritizing food sovereignty over social prestige.
\end{abstract}

Keywords: Food Sovereignty; Hunger; mnemonic device; Season Calendar

\begin{abstract}
Abstrak
Kedaulatan pangan adalah solusi bagi kelaparan. Namun demikian di Sumba Barat Daya, kondisi lapar tersebut berkelindan menyatu dengan perubahan kondisi alam, sosial, ekonomi, dan budaya. Pengadaan dan kecukupan pangan pun dibayangkan bertautan dengan kebutuhan untuk memenuhi kontrak-kontrak sosial dalam komunitas setempat, yaitu dengan moralitas yang ditampilkan melalui rangkaian ritual daur hidup sepanjang tahun. Kelindan pengadaan pangan, yang utamanya lewat kegiatan pertanian dan peternakan, dengan rangkaian kegiatan ritual ini diperlukan penataan agar hidup lebih terorganisir dan adaptif terhadap perubahan lingkungan. Kelindan ini secara tradisional telah diantisipasi menggunakan berbagai macam media. Salah satu di antaranya adalah kalender musim yang di Sumba Barat Daya dan banyak tempat lain sudah terabaikan. Oleh karena itu, artikel ini menyajikan aplikasi kalender musim sebagai mnemonic device yang dapat membantu petani, untuk menemukenali kembali jiwa alam sehingga mereka dapat bertani selaras dengan irama alam. Selain itu, kalender musim menjadi sarana pencatatan mengenai tanda-tanda alam yang selama ini samar, sehingga petani mampu menyeimbangkan diri antara kepentingan pemenuhan komoditas dan juga pemenuhan
\end{abstract}




\section{p-ISSN 1412-9418 e-ISSN 2502-5783 \\ Humanika Vol. 28 no 1 Copyright @2021 \\ Available online di http://ejournal.undip.ac.id/index.php/humanika}

kebutuhan hidupnya. Secara partisipatoris penelitian dilakukan selama tiga tahun, yaitu tahun pertama menghasilkan identifikasi masalah; tahun kedua menghasilkan rumusan model kedaulatan pangan, dan tahun ketiga berisi rangkaian workshop uji coba model. Artikel ini khusus mengulas bagaimana model kedaulatan pangan yang berupa mnemonic device itu diperkaya melalui serangkaian workshop, yang diikuti para pemangku kepentingan di Sumba Barat Daya serta komunitas mahasiswa Sumba yang ada di Yogyakarta. Pengayaan kalender musim ini diharapkan mempermudah serta memperluas aksesibilitas penggunanya secara lintas gender, usia, dan strata sosial. Apresiasi kalender musim akan menjamin petani insaf akan pentingnya mendahulukan kedaulatan pangan daripada gengsi sosial.

Kata Kunci: Kedaulatan Pangan; Kelaparan; mnemonic device; Kalender Musim.

\section{Pendahuluan}

Artikel ini antara lain menyarankan agar kita insaf dari sesat sudut pandang terhadap masalah kelaparan dan agar masyarakat petani juga mampu menyeimbangkan diri di antara kepentingan pemenuhan komoditas, sekaligus pemenuhan kebutuhan hidupnya. Inisiatif dan inovasi dalam adaptasi literasi baru pertanian masyarakat ini diperlukan sebagai salah satu jawaban pada tantangan peralihan sesuai dengan keadaan masa kini. Oleh karena itu, diperlukan penghubung yang dapat digunakan untuk masyarakat dalam memenuhi keperluan beradaptasi tersebut, yaitu sebuah media atau mnemonic device yang berupa kalender musim. Pada masa lalu, masyarakat antara lain melembagakan tata musim alami atau pranatamangsa ${ }^{1}$ yang merefleksikan spiritualitas bumi, yaitu hasil pencaripaduan hidup dengan irama alam untuk menyelaraskan budidaya tanaman pangannya dengan musim.

Kelaparan mengingatkan bahwa sesungguhnya kehendak dan kekuatan paling dasar dari mereka yang lapar untuk melindungi diri dan keluarga yang dicintainya telah dirampok, sehingga akar

1 Daldjoeni (1984) menyebutkan bahwa Pranatamangsa merupakan suatu kearifan lokal yang berisi tentang pembagian waktu yang sejak lama dikenal oleh masyarakat di Pulau Jawa dan kelaparan bukanlah kelangkaan makanan atau tanah; tetapi kelangkaan demokrasi. (Lappé et al., 1997, p. 4). Begitulah kelaparan kemudian dipahami hanya sebagai perkara teknis dan diselesaikan oleh para ahli sementara mereka yang miskin, utamanya para perempuan tersisih, tidak dilihat sebagai agen aktif yang mendefinisikan dan mengatasi kerawanan pangannya sendiri. Seandainya mereka punya pangan, maka pangannya dianggap tidak berkualitas dan tidak bernutrisi sehingga mereka dikatakan mengalami hidden hunger atau kelaparan tersembunyi (malnutrisi). Makanannya dianggap sebagai pengisi perut saja (Kimura, 2013, p. 18). Di Sumba dan di tempat-tempat terpencil di Indonesia, asupan pangan sepanjang tahun bahkan belum mencukupi sehingga ancaman kelaparan nyata, tentu juga yang tersembunyi, dan masih laten.

Makanan niscaya merupakan persoalan mendasar. Mata rantai sistem makanan bukanlah perkara tubuh atau raga semata, karena ia berkelindan dengan wacana sosial budaya, ekonomi, dan politik. Kekuatan politik yang terpusat dan privatisasi telah mengontrol semua aspek sistem produksi pangan mulai dari benih, input, tanah, dan kebutuhan lainnya

telah dibukukan oleh Pakubuwono VII dan Ranggawarsita tahun 1855. Pranatamangsa menjadi pedoman formal dalam berbagai aktivitas sosial dan ekonomi masyarakat terutama kegiatan bercocok tanam. 


\section{Available online di http://ejournal.undip.ac.id/index.php/humanika}

(Campesina, 2018: 27). Selanjutnya, kekurangan asupan nutrisi dijawab secara akademik dengan penambahan zat penguat gizi melalui rekayasa teknis dan kimiawi yang efisien dalam industri bahan makan massal. Pangan manusia dan cita rasanya dibuat dan ditentukan oleh industri. Tumbuh-kembang dan raga manusia pun terpaksa mengikuti kehendak industri. Situasi itu niscaya berlawanan dengan kebiasaan dalam rumah-tangga tradisional. Etnografi James T. Siegel (1993, pp. 192-193) misalnya, menemukan bahwa para perempuan di Solo menetapkan statusnya dengan menguasai selera makan keluarganya. Mereka memantapkan rasa manis, pahit, asin dan pedas makanan yang diolahnya sebagai negativitas, rasa yang pasti khas tetapi beda dari rasa makanan lain. Para perempuan memastikan tidak mungkin ada makanan lain seenak olahannya. Mereka mendemonstrasikan bahwa kedaulatan pangan dibutuhkan untuk mengartikulasikan relasi-relasi sosial budaya sehari-hari.

Mengacu kepada UU No 18 Tahun 2012 (UU No. 18 Tahun 2012 Tentang Pangan [JDIH BPK RI], n.d.), Kedaulatan Pangan adalah hak negara dan bangsa yang secara mandiri menentukan kebijakan pangan yang menjamin hak pangan bagi rakyat dan yang memberikan hak bagi masyarakat untuk menentukan sistem pangan yang sesuai dengan potensi sumber daya lokal. Lebih daripada itu, kedaulatan pangan adalah jaminan bagi kelestarian hidup, yang bagaimana pun mengandalkan proses transformasi pengetahuan melalui pendidikan dan manajemen pengolahan pangan. Transformasi ini adalah hak bagi generasi selanjutnya (Pimbert, 2008, p. 13) yang juga mencakup hak wajar atas tanah dan 'hak untuk berproduksi' (Rosset, 2011, pp. 22-23)
Dalam wacana ilmu antropologi, pangan bukan hanya masalah pemenuhan karbohidrat, tetapi juga masalah substansi naratif. Sebelum masuk ke dalam tubuh bahan makanan itu mengalami transformasi menjadi rangkaian narasi (mitos). Claude Lévi-Strauss menyatakan adanya syarat agar spesies alami (makanan) itu enak dimakan (bon à manger). Pertama-tama makanan itu dipikir-pikir serta diceritakan enak (bon à penser) dalam pikiran kolektif hingga mentradisi dan dianggap cocok untuk perut mereka. Katanya: "We can understand, too, that natural species are chosen not because they are "good to eat" [bonnes à manger] but because they are "good to think" [bonnes à penser]" (Levistrauss, 1963). Dari sinilah urusan pangan itu melekat pada kearifan lokal, yang berisi kisah pemecahan masalah hidup seharihari yang khas, bahkan identik dengan komunitasnya.

PM Laksono (2017) menemukan di Kepulauan Kei, bagaimana komunitas lokal mengubah makanan pokok mereka, dari singkong beracun yang disebut embal, menjadi cetusan identitas. Misalnya, para perantau asal Kei di berbagai tempat akan merasa sebagai orang Kei ketika mereka mendapat kiriman embal dari kampungnya. Di Sumba Barat, kami juga mendapati betapa orang Sumba mengonsumsi daging nyaris hanya secara sosial di saat pesta adat. Mereka, yang mencoba belanja daging di pasar, akan dapat sindiran sebagai orang yang tidak punya keluarga. Pengadaan dan kecukupan pangan pun dibayangkan berkelindan dengan kebutuhan untuk memenuhi kontrakkontrak sosial dalam komunitas setempat, yaitu dengan moralitas yang ditampilkan melalui rangkaian ritual daur hidup sepanjang tahun. Kelindan pengadaan pangan, yang utamanya lewat kegiatan pertanian dan peternakan, dengan rangkaian kegiatan ritual itu memerlukan 


\section{p-ISSN 1412-9418 e-ISSN 2502-5783 \\ Humanika Vol. 28 no 1 Copyright @2021 \\ Available online di http://ejournal.undip.ac.id/index.php/humanika}

penataan agar hidup lebih terorganisir dan adaptif terhadap perubahan lingkungan. Keseluruhan produksi bahan pangan seyogyanya dapat dibagi untuk mencukupi kebutuhan makan perseorangan dan sosial sehari-hari sepanjang tahun. Namun demikian, para petani Sumba Barat Daya berbudidaya tanaman pangan cenderung ikut arus tetangga kiri kanan. Pilihan tanaman dan saat penanaman sekadar ikut-ikutan tetangga. ${ }^{2}$

Ada kebutuhan re-edukasi agar para petani mampu berdiri di atas kakinya sendiri mengatasi kecukupan pangannya. Ancaman kelaparan tidaklah cukup hanya dijawab dengan memacu pengadaan beras berumur pendek beserta teknologinya, sementara petani dibiarkan abai pada potensi dan budidaya pangan lokal yang dimilikinya. Akibatnya sudah terjadi, ketika paceklik tiba, orang hanya mengaku kurang beras. Kelaparan hanya diartikan tidak ada beras. Mnemonic device dapat membantu para petani untuk "membaca" tanda alam. Alat ini dapat mencatat dan menghubungkan peristiwa alam dan kultural dalam bentuk narasi kebenaran yang mudah diingat.

Selain sebagai sarana pengingat, tujuan sebuah Mnemonic device dibuat adalah untuk menyediakan alat wacana bagi komunitas untuk keluar dari tekanan struktural. Komunitas merupakan suatu bentuk dari kebersamaan yang menghilangkan superioritas, insekuritas, dan juga merangkul pihak-pihak yang termarginalkan dari struktur tersebut (Turner, Victor, 1969, p. 96). Dasar dari komunitas itu adalah kesamaan berbagi pengalaman merasakan tekanan yang sama. Dengan pengalaman bersama itu komunitas memiliki solidaritas kolektif yang dapat digali, dipolakan, dan diperkuat

\footnotetext{
${ }^{2}$ Ini seperti petani Gunung Kidul yang dilihat Gunawan (2017) ketika terjebak dalam mobilisasi
}

melalui diskusi terpumpun. Mnemonic device menjadi sarana agar komunitas dapat mengingat banyak pengalaman kolektif mereka terhadap peristiwa seperti kelaparan, perubahan musim, acara adat maupun sosial-budaya lain.

\section{Metode Penelitian}

Setelah penelitian partisipatoris tahun 2018 dan 2019 di lokasi yang sama, penelitian ini dilakukan dengan sejumlah diskusi terpumpun (FGD), yaitu dua kali dengan para mahasiswa Sumba di Yogyakarta; satu kali dengan para pejabat dinas dan aktivis pengembangan dan penguatan pangan lokal di Kota Weetabula; masing-masing dua kali dengan warga masyarakat di Desa Waikaninyo, Kecamatan Kodi Bangedo, Desa Pero Batang, Kecamatan Kodi; dan di Desa Laga Lete, Kecamatan Wewewa Barat. Diskusi terpumpun (FGD) di masingmasing desa dilakukan pada dua kelompok, yaitu kelompok perempuan dan kelompok yang terdiri dari perangkat desa, sarjana pertanian desa, kelompok tani, tokoh adat seperti Rato dan Wunang. Diskusi terpumpun (FGD) menjadi metode proses dialog antara peneliti dan tineliti dalam menanggapi hasil temuan penelitian tahun 2019 dalam kalender musim. Dengan demikian peneliti dan tineliti dapat mencermati, merefleksikan, dan mengevaluasi kegiatan sosial, ekonomi dan budaya secara bersama-sama untuk menentukan rencana dan taktik strategis di tahun yang akan datang supaya terhindar dari kelaparan pada musim paceklik di Bulan Januari dan Februari.

penanaman jatropha (jarak pagar. Mereka anut grubyuk tanam jantropa). 
Humanika Vol. 28 no 1 Copyright @2021

Available online di http://ejournal.undip.ac.id/index.php/humanika

Penelitian partisipatoris kalender musim ini dilakukan di dua jenis topografi yang sangat kontras. Bagaimanapun pola sosial, ekonomi, dan budaya masyarakat tarik menarik dengan unsur alaminya. Topografi dataran rendah-pesisir di Desa Waikaninyo, Kecamatan Kodi Bangedo dan Desa Pero Batang, Kecamatan Kodi serta topografi dataran tinggi di Desa Laga Lete, Kecamatan Wewewa Barat. Curah hujan di
Desa Waikaninyo relatif lebih rendah dibandingkan Desa Pero Batang, meskipun terletak pada jenis topografi yang sama. Sedangkan, Desa Laga Lete diakui para informan memiliki curah hujan yang relatif tinggi. Para peneliti memandu peserta diskusi hingga dapat mengenali kembali situasi lingkungan sosial-ekonomi dan alamnya secara kritis, bahkan mampu mengkritisi perilakunya sendiri.

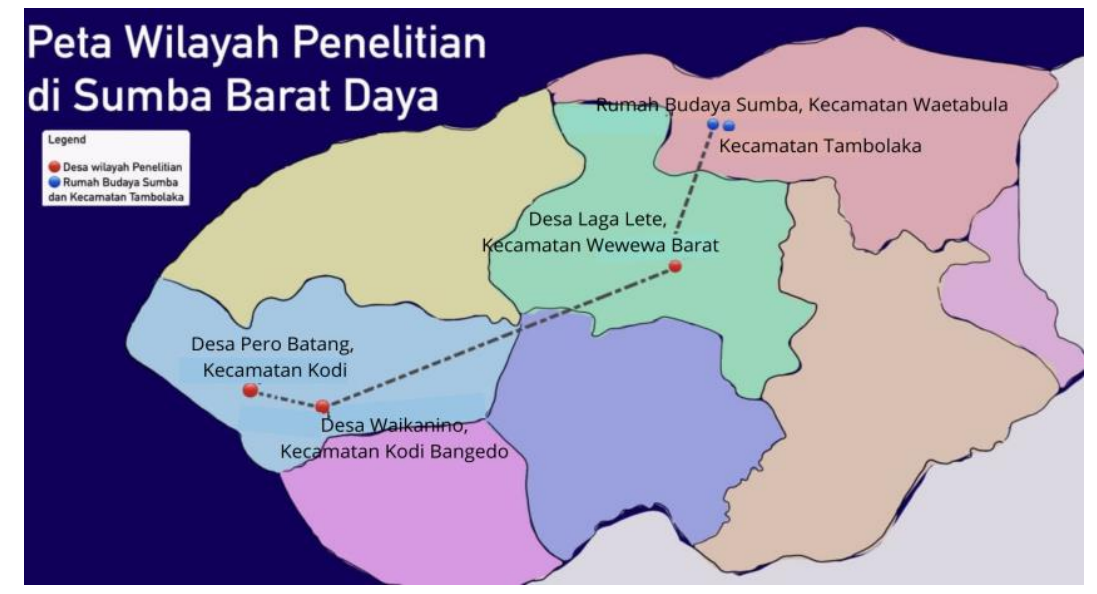

Gambar 1. Peta wilayah penelitian kedaulatan pangan di Sumba Barat Daya

Stephen Kemmis dan Robin McTaggart (2005, p.560) menyatakan bahwa riset partisipatoris ditunjang oleh tiga hal mendasar. Pertama, adanya pemahaman atau sudut pandang yang sama dalam sebuah komunitas terhadap suatu isu. Kedua, penelitian ini berdasarkan pada analisis yang dibangun sendiri oleh komunitas. Analisis tersebut terbentuk dari pengungkapan masalahmasalah yang ada di dalam komunitas tersebut. Ketiga, metode ini mengajak komunitas untuk memecahkan permasalahan yang telah mereka temukan berdasarkan kesepakatan bersama dan menjadi kritik diri terhadap komunitasnya (Kemmis dan McTaggart, 2005, p. 560).

Selanjutnya, pilihan metode kami mengacu pada langkah perubahan kebudayaan yang disarankan Ki Hadjar Dewantara. Perubahan harus mengikuti asas Trikon (Kontinyu, Konsentrik, dan
Konvergen). Asas Trikon ini merupakan prosedur dasar yang perlu diikuti agar pembangunan dapat sungguh-sungguh berkelanjutan. Trikon memberikan langkah berpikir yang bersifat bottom-up sehingga komunitas atau masyarakat terus-menerus turut serta terlibat, mengulirkan kearifan tradisionalnya berkonvergensi dengan dunia baru (Laksono, 2018, pp. 134-136). Kami memahami, bahwa koherensi atribut kualitatif dari peristiwa itu tidak tunggal tetapi bersifat polisemi, jadi bersifat kontekstual dan memuat banyak tafsir.

\section{Hasil dan Pembahasan}

\section{Proses Awal Penggunaan Kalender Musim}

Gagasan awal untuk menghasilkan alat peraga Kalender Musim ini bermula dari serangkaian diskusi di antara para peneliti 


\section{p-ISSN 1412-9418 e-ISSN 2502-5783 \\ Humanika Vol. 28 no 1 Copyright @2021 \\ Available online di http://ejournal.undip.ac.id/index.php/humanika}

untuk menemukan media gerakan Sumba Barat Daya berdaulat pangan, yaitu alat peraga proses literasi yang dapat menggugah masyarakat lokal untuk menemukenali potensi sumber daya pangan lokal sepanjang tahun. Kami kemudian merekayasa sistem kalender yang dapat mempertautkan sistem gagasan (budaya), tindakan sosial, kepribadian, dan organisme (ekologi) di Kabupaten Sumba Barat Daya. Dengan bantuan alat ini, kami berharap para

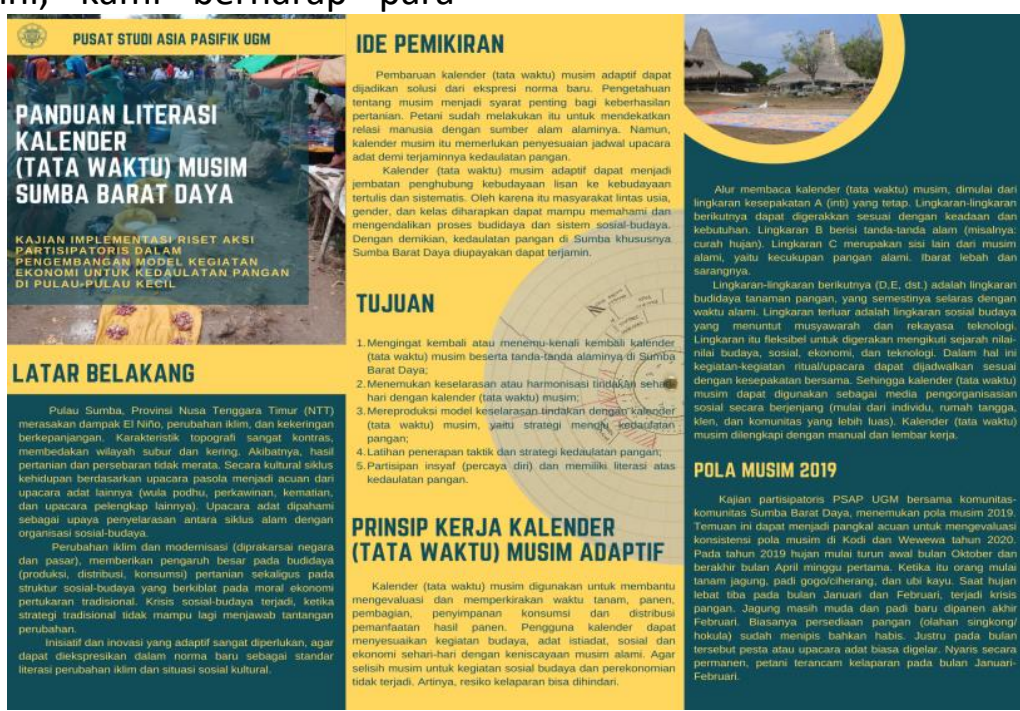

Gambar 2. Leaflet Halaman 1: Panduan literasi Kalender Musim di Sumba Barat Daya

Gambar 3 memperlihatkan bagaimana alur membaca kalender musim itu, dimulai dari lingkaran kesepakatan A (inti) yang tetap dan berisi nama-nama bulan dalam satu tahun. Lingkaranlingkaran berikutnya dapat digerakkan sesuai dengan keadaan dan kebutuhan. Lingkaran $B$ berisi tanda-tanda alam (misalnya: curah hujan). Lingkaran $C$ merupakan sisi lain dari musim alami, yaitu kecukupan pangan alami. Lingkaranlingkaran berikutnya ( $D, E$, dst.) adalah lingkaran budidaya tanaman pangan, yang semestinya selaras dengan waktu alami. pengguna dapat menyelaraskan kegiatan budaya, adat istiadat, sosial dan ekonomi sehari-hari dengan keniscayaan musim alami, sehingga pilihan hidupnya tidak mengalami selisih musim dan jatuh lapar. Untuk melengkapi alat ini kami menyiapkan panduan untuk memudahkan penggunanya (Gambar 2.) 


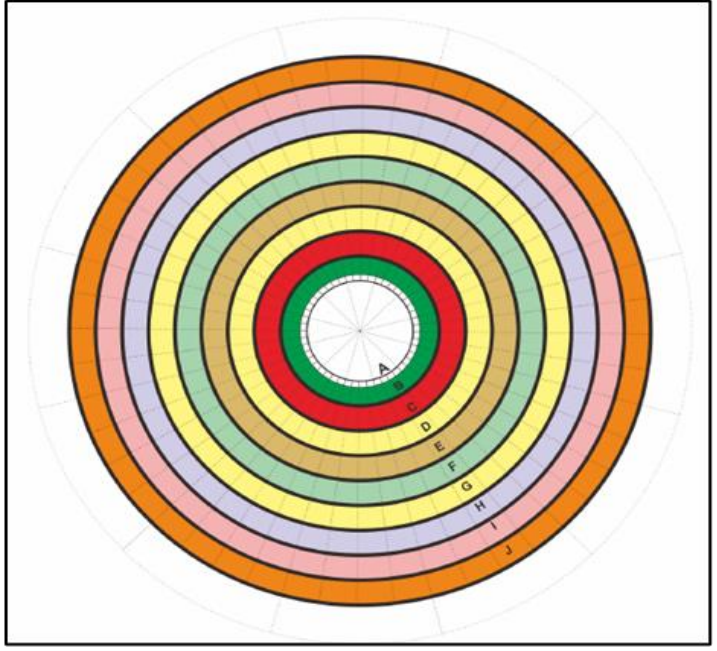

Gambar 3. Ilustrasi Kalender Musim

Kajian partisipatoris tim bersama komunitas-komunitas Sumba Barat Daya telah menemukan pola musim 2019. Temuan ini dapat menjadi pangkal acuan untuk mengevaluasi konsistensi pola musim di Kodi dan Wewewa tahun 2020. Pada tahun 2019 hujan mulai turun awal bulan Oktober dan berakhir bulan April minggu pertama. Ketika itu orang mulai tanam jagung, padi gogo dan ciherang, serta ubi kayu. Saat hujan lebat tiba, pada bulan Januari dan Februari terjadi krisis pangan. Jagung masih muda dan padi akan dipanen akhir Februari. Biasanya, persediaan pangan (hokula-olahan ubi kayu (semacam tiwul di Jawa) sudah menipis bahkan habis. Justru pada bulan tersebut pesta atau upacara adat seperti bangun rumah, gali kubur, angkat jiwa, dan lainnya biasa digelar. Nyaris secara permanen, petani terancam kelaparan pada bulan Januari-Februari. Pola musim tahun berjalan (2020) dibicarakan bersama untuk mengingat persamaan dan perbedaannya dengan pola musim sebelumnya (2019). Panduan rinci penggunaan kalender ini dalam proses FGD disediakan terpisah dan dapat memudahkan penggunanya. Para peserta diskusi dapat menorehkan catatannya pada plano kosong kalender untuk evaluasi pola musim tahun berjalan. Dari catatan mereka sendiri misalnya akan dapat ditemukan bagaimana anomali cuaca dapat mengganggu siklus kehidupan serangga, serta hewan-hewan lain yang biasanya secara instingtif tergantung pada putaran musim, perbedaan suhu, serta kelembaban udara dan tanah. Bila pola musim tahun berjalan sama dengan tahun 2019 dan belum ada perubahan pola budidaya tanaman pangan, maka peserta diskusi akan insaf bahwa pada bulan Januari dan Februari niscaya musim lapar akan terulang di tahun yang akan datang (2021). Mereka kemudian dapat mengambil langkah-langkah bersama menentukan siasat yang tepat menghadapi bulan lapar.

\section{Memetik Manfaat Kalender Musim}

Dialog kedaulatan pangan di Sumba Barat Daya antara peneliti dengan tineliti melalui media kalender musim di sejumlah kelompok yang terdiri dari para mahasiswa Sumba di Yogyakarta, pemangku kepentingan daerah, aktivis yang bergerak di bidang kedaulatan pangan Sumba Barat Daya, dan kelompok masyarakat di Desa Waikaninyo, Kecamatan Kodi Bangedo; Desa Pero Batang, Kecamatan Kodi; dan Desa Laga Lete, Kecamatan Wewewa Barat menghasilkan respon dan tanggapan yang berbeda-beda sesuai dengan sejarah dan pengalaman masing-masing peserta kelompok diskusi. 
Diskusi pertama dilaksanakan di kantor Pusat Studi Asia Pasifik UGM dengan mengundang perwakilan mahasiswa Sumba di Yogyakarta. Kelompok mahasiswa tersebut dibagi menjadi tiga kelompok, yaitu kelompok pertanian di Kodi, Wewewa, dan Anakalang, Sumba Tengah. Diskusi ini menghasilkan kumpulan data verifikasi dari hasil penelitian 2018 dan 2019 untuk mengidentifikasi gejala ekonomi, sosial, dan budaya khususnya pangan di Sumba. Pada tahap ini, kalender ini dicoba pertama kali dikaji bersama perwakilan mahasiswa Sumba di Yogyakarta.

Pertemuan ini dilakukan sebanyak dua kali. Pada pertemuan pertama, fasilitator mengajak para peserta untuk menemukenali kembali dan juga mengingat menu makanan sehari-hari peserta saat masih berada di kampung halaman. Setelah itu, fasilitator mengajak peserta menguraikan peristiwa yang berkaitan dengan urusan pangan mulai dari produksi, distribusi hingga konsumsi di lingkungan sekitar mereka mulai dari rumah, desa, hingga tingkat kecamatan. Kemudian di hari dan waktu yang berbeda, pada pertemuan kedua fasilitator mengajak peserta mengisi dan mengoperasikan kalender musim yang ada di daerah mereka masing-masing.

Diskusi kedua dilaksanakan di Rumah Budaya Sumba, Kota Weetabula, Sumba Barat Daya dengan mengundang para pemangku kepentingan dan aktivis yang bergerak di bidang kedaulatan pangan. Kegiatan diskusi dibagi menjadi empat kelompok kecil, yaitu kelompok Kodi A, Kodi B, Wewewa A, dan Wewewa B. Pada anggota kelompok Kodi $A$ hanya terdapat satu orang berasal dari Kodi dataran tinggi, yaitu daerah Kecamatan Kodi dekat dengan Kota Weetabula, dua orang berasal dari Yogyakarta dan satu orang berasal dari Flores. Dari keempat peserta diskusi terdapat satu orang aktivis, dua orang pegawai sipil daerah Sumba Barat Daya, dan satu orang mantan kepala pendamping kelompok tani di Sumba Barat Daya. Ketika fasilitator menjelaskan ringkasan cara membaca dan menggunakan cara kerja kalender musim, seorang aktivis dan seorang pegawai sipil daerah langsung memberikan respon, bahwa temuan kalender musim pertanian ini sudah pernah ada, namun teknologi dan pengetahuannya tidak didistribusikan dengan baik, sehingga tidak ada yang menggunakan kalender pertanian tersebut.

Selanjutnya, fasilitator mengajak para peserta diskusi untuk mencermati temuan tim peneliti tahun 2019 pada kalender musim. Seluruh peserta diskusi sepakat temuan tim peneliti tahun 2019 relevan dengan pola budidaya tanaman bahan pangan dan sosial atau pesta adat yang ada di daerah Kodi, bahkan tidak ada perubahan pada tahun yang sedang berlangsung (2020). Dengan demikian, peserta menentukan garis kelaziman atau imajiner tahun 2020 dengan warna biru di samping atau di atas garis kelaziman atau imajiner tahun 2019. Selanjutnya, fasilitator mengarahkan peserta untuk mencermati, merefleksikan dan mengevaluasi pola budidaya bahan pangan dan sosial budaya untuk menentukan taktik strategis di tahun 2021. Seluruh peserta saling berdiskusi dan sepakat, bahwa pola tanam dan sosial tahun 2019 dan 2020 semestinya tidak menimbulkan kelaparan pada bulan paceklik, karena pada saat musim tanam pertama padi, jagung, dan ubi kayu di bulan Oktober minggu pertama. Pada saat itu, biji mete dipanen lalu dijual ke tengkulak untuk mendapatkan uang tunai yang dapat digunakan kembali untuk membeli beras.

Pada rentang waktu bulan November hingga awal Januari, masyarakat makan nasi dengan campuran 
jenis kacang-kacangan dan mulai mengolah hokula untuk selingan bahan pangan. Ketika berdiskusi, sesaat mereka hening, mencermati pernyataan mereka. Hingga akhirnya, peserta yang berasal dari Kodi berpendapat bahwa dengan pola tanam bahan pangan dan sosial yang selama ini diterapkan, pada kenyataannya orang di kampung-kampung banyak yang tidak bisa makan, karena persediaan pangan menipis bahkan habis. Menurut mantan kepala pendamping kelompok tani, perlu adanya peningkatan atau perluasan pengolahan lahan untuk budidaya jagung rote (watar piyo) atau sorghum yang ditanam bersamaan dengan padi, jagung, dan ubi kayu.

Daya tahan penyimpanan sorghum lebih tahan lama, sehingga dapat dikonsumsi pada bulan-bulan krisis pangan atau paceklik. Lalu peserta menentukan dan memberikan tanda tanam dan panen untuk jenis tanaman bahan pangan (baru) atau sorghum pada lapisan lingkaran bahan pangan lainnya di kalender musim. Selanjutnya, seorang peserta mencermati taktik strategis kalender musim 2021 pada bagian lingkaran pesta adat. Menurutnya, perlu ada sebuah pertemuan dengan para tokoh adat seperti rato dan wunang untuk menentukan kesepakatan rentang waktu upacara atau pesta adat di luar kematian yang sifatnya tidak dapat diprediksi manusia. Pada saat musim upacara atau pesta adat pada bulan Juni hingga Maret, banyak nasi yang dibuang begitu saja, padahal pada bulan paceklik mengalami kelaparan.

Setelah berdialog untuk membaca dan mengoperasikan kalender musim ini, peserta sepakat bahwa alat ini dapat digunakan di kelompok-kelompok sesuai dengan kebutuhan dan taktik strategisnya masing-masing terkait topografi dan curah hujan di wilayahnya. Kelompok ini sepakat untuk mulai membudidayakan (kembali) jenis tanaman bahan pangan sorghum, menata rentang waktu upacara atau pesta, dan menggunakan sistem teknologi pengolahan lahan yang ramah lingkungan. Mereka sepakat ini merupakan satu langkah bijak untuk terbebas dari wacana gizi buruk dan kelaparan di Sumba Barat Daya. Salah satu peserta FGD mengatakan "(Alat) Ini sangat menolong. Karena kami hidup dengan warga-warga sederhana yang butuh sesuatu lekat pada mata. (suatu yang nyata) dalam artian kita butuh insaf". Sesuatu yang lekat mata artinya mudah dilihat. Alat yang mudah dilihat tersebut memungkinkan adanya hal yang transparan dan bersifat demokratis. Dengan demikian, alat ini merupakan sarana untuk bermusyawarah warga agar dapat mengatasi krisis atau paceklik.

Diskusi ketiga dilaksanakan di rumah Kepala Desa Pero Batang, Kecamatan Kodi dengan mengundang kelompok perempuan serta perangkat desa, kelompok tani, sarjana pertanian desa, tokoh adat seperti Rato dan Wunang. Kegiatan diskusi dibagi menjadi empat kelompok diskusi kecil, yaitu kelompok $A$ (perempuan) dan kelompok B, C, D (perangkat desa dan tokoh adat). Anggota kelompok $B$ terdiri dari empat orang lakilaki, yaitu perangkat desa, ketua pendamping kelompok tani wilayah Kodi, Rato, dan Wunang. Masing-masing peserta diskusi berasal dari Kecamatan kodi. Awalnya kelompok diskusi ini didominasi oleh ketua pendamping kelompok tani, karena ia yang paling lancar berbahasa Indonesia. Sementara itu, kedua tokoh adat awal mulanya cenderung pasif, karena mereka tidak bisa berbahasa Indonesia. Kemudian salah seorang peserta harus membahasakan penjelasan fasilitator dan pendapat ketua kelompok tani dengan bahasa Kodi. Setelah fasilitator menjelaskan ringkasan cara membaca dan menggunakan cara kerja kalender musim, ketua kelompok tani langsung meresponnya. Katanya, media kalender 
musim ini baik untuk mengatur dan memperkirakan persediaan bahan pangan di musim-musim paceklik pada Bulan Januari-Februari.

Tahap berikutnya, fasilitator mengajak para peserta diskusi untuk mencermati temuan tim peneliti tahun 2019. Mereka sepakat bahwa temuan tim peneliti sesuai dengan pola budidaya bahan pangan dan sosial warga masyarakat di Kodi. Tidak ada perubahan pola tanam pada tahun 2020, namun ada perubahan rentang waktu upacara atau pesta adat di Kodi. Pada awal bulan Maret 2020, sejumlah ternak babi mati karena terserang virus babi. Bahkan tercatat, ada satu keluarga yang 40 ekor babi peliharaannya mati karena virus. Hewan ternak babi pun jadi sangat langka, harganya melambung tidak normal. Akibatnya, rentang waktu pesta adat yang dimulai pada bulan Juni hingga Maret, pada tahun 2020 ini ditiadakan, kecuali untuk upacara atau ritual adat kematian masih diperbolehkan. Dengan kesepakatan tokoh adat dan keluarga besar (kabihu), upacara atau pesta adat selain kematian ditunda hingga awal tahun 2021 bila keadaan sudah memungkinkan.

Tahap selanjutnya, fasilitator mengarahkan peserta untuk mencermati, merefleksikan dan mengevaluasi pola budidaya bahan pangan dan sosial budaya tahun 2019 dan 2020 untuk menentukan strategi dan taktik 2021. Dengan adanya penundaan pesta tersebut, seluruh peserta sepakat bahwa persediaan pangan pada bulan November-Desember masih cukup hingga bulan Januari-Februari. Seperti biasanya, perempuan mengolah nasi dengan bahan campuran kacangkacangan dan jagung. Bahkan, beberapa

\footnotetext{
${ }^{3}$ Sebutan jagung gogo digunakan untuk menyebut jagung lokal. Masyarakat Sumba Barat Daya juga menyebutnya dengan istilah jagung gogo koko.
}

keluarga sudah mulai mengolah hokula untuk persediaan bahan pangan di bulan Desember dan Januari, karena persediaan pangan menipis. Hasil penjualan panen jambu mete dan tembakau dikelola perempuan untuk membeli beras di pasar. Salah satu peserta perempuan memberikan pendapat setelah mengikuti FGD ini, dia berkata, "Bulan Nyale adalah bulan krisis, khususnya di Kodi. (Pada) Bulan tidak ada apa-apa, tetapi itu pun kami tetap berusaha untuk mencari (bahan makanan). Jadi, pada saat bulan Nyale itu kami tetap lakukan (mencari bahan makanan). Bulan Nyale tidak bisa digeser lagi, pas tanggal dan bulan yang dipastikan itu harus dilaksanakan. (Alat ini membantu) jadi lebih fokus lagi, (kami) menambah ilmu dari kalender ini. Karena di dalam kalender ini tidak jauh dari pemahaman kami di sini, untuk cara menanam"

Melalui proses pembacaan dan pengoperasian kalender musim ini mereka sadar bahwa peran ekonomi perempuan dari hasil menenun kain selama ini sangat membantu meemenuhi kebutuhan keluarga dan sekolah anak. Menurut mereka jika dilihat dan dicermati dari pola budidaya bahan pangan (jagung, padi dan ubi kayu) dan jambu mete serta sumber daya pelengkap lain, lazimnya persediaan pangan akan cukup, namun kenyataannya pada bulan-bulan paceklik persediaan pangan sangat terbatas. Bahkan, salah satu peserta mempertanyakan mengapa gizi buruk pada anak di Sumba cukup tinggi. Berdasarkan hasil diskusi antar peserta dan perenungan mereka masing-masing, perlu adanya peningkatan pengolahan lahan untuk budidaya bahan pangan, khususnya jagung gogo ${ }^{3}$ karena daya tahan 
Humanika Vol. 28 no 1 Copyright @2021

\section{Available online di http://ejournal.undip.ac.id/index.php/humanika}

penyimpanan relatif tahan lama dibanding jagung hibrida. Selain itu, mereka sepakat perlu adanya negosiasi upacara atau pesta adat yang lebih memperhitungkan keadaan pola budidaya bahan pangan dan ketersediaan hewan miliknya atau kerabat lainnya yang terintegrasi dalam ikatan sosial.

Diskusi keempat dilaksanakan di rumah Kepala Desa Laga Lete, Kecamatan Wewewa Barat dengan mengundang kelompok perempuan serta perangkat desa, kelompok tani, tokoh adat seperti Rato. Kegiatan diskusi dibagi menjadi tiga kelompok diskusi kecil, yaitu kelompok $A$ (perempuan) dan kelompok B, C (perangkat desa dan tokoh adat). Kelompok A terdiri dari lima orang perempuan (Gambar 4). Sehari-hari mereka mengurus rumah tangga dan bertani di ladang. Kelima peserta diskusi mampu berbahasa Indonesia, sehingga tidak ada kendala komunikasi dalam kelompok.

Ketika fasilitator menjelaskan cara membaca dan mengoperasikan alat ini, mereka mencermati dengan seksama dan tidak memberikan tanggapan. Kemudian fasilitator menyampaikan, bahwa kalender ini merupakan hasil penelitian 2018 dan 2019, yang datanya diperoleh dari diskusi terpumpun (FGD) dengan para pendamping pertanian di Yayasan Donders dan Mahasiswa Sumba di Yogyakarta. Berangkat dari berbagai keterbatasan, tim hanya bisa melakukan observasi dan wawancara di Desa Pero Batang, Kecamatan Kodi pada tahun 2018 dan 2019. Oleh karena itu, data pola budidaya bahan pangan dan sosial di Wewewa sifatnya masih sangat umum, sehingga memungkinkan adanya tambahan spesifik di wilayah Desa Laga Lete, Kecamatan Wewewa Barat. Setelah itu, peserta diskusi baru mulai aktif menyampaikan perbedaan dan pergeseran khususnya data curah hujan dan pola tanam. Curah hujan jauh lebih lama, mulai minggu pertama Oktober dan berakhir di akhir April. Sama seperti di kelompok diskusi sebelumnya, saat hujan pertama warga mulai menanam jagung, padi sawah, padi ladang, dan menanam ubi kayu sebagai tanaman pagar. Mereka memiliki jenis komoditas lain selain bahan pangan, seperti kopi dan kemiri yang dapat dipanen mulai Bulan Juli hingga September.

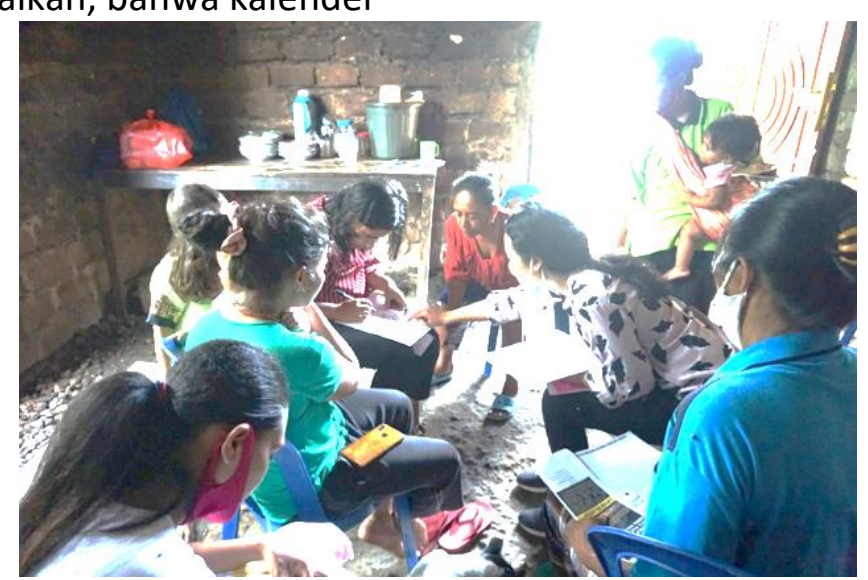

Gambar 4. Kelompok perempuan di Desa Laga Lete sedang berdiskusi dan belajar menggunakan Kalender Musim.

Para peserta diskusi sepakat bahwa pada saat curah hujan tinggi, terjadi ancaman kelaparan yang biasanya terjadi pada bulan Januari hingga minggu kedua Februari. Namun, bagi seluruh peserta diskusi, faktor ancaman kelaparan juga terjadi karena pengelolaan/pengaturan waktu upacara atau pesta adat mulai bulan Juni hingga Februari, di mana puncak acara pada bulan Oktober hingga awal Januari. 
Dengan mencermati alat ini, peserta diskusi menjadi berpikir kritis, menurut mereka seharusnya jika dilihat dari faktor alaminya, tidak mungkin terjadi kelaparan pada bulan Januari-Februari karena minggu kedua Desember sudah mulai panen jagung dan mulai memiliki hasil panen padi ladang pada bulan April dan mulai panen padi sawah pada bulan Juni.

Melalui proses belajar bersama, kelompok ini sepakat untuk tidak menambah jenis bahan pangan lain, karena secara geografis karakteristik tanah dan lahan mereka sudah cocok dengan jenis bahan pangan jagung, padi sawah, padi ladang, dan ubi kayu. Persoalan utama bagi peserta diskusi, sering kali suami menerima undangan pesta tanpa kesepakatan istri/perempuan. Perempuan tidak diperhitungkan pendapatnya dalam urusan upacara atau pesta adat. Mereka bahkan sepakat untuk mengatur upacara dan pesta adat di luar kematian seperti bangun rumah, gali tulang, perkawinan pada Bulan Agustus hingga September, karena bulan Juni-Juli harus membayar biaya sekolah anak, dan pada awal Oktober warga sudah mulai kerja ladang untuk persiapan musim tanam. Pada kelompok perempuan, salah satu peserta FGD menuturkan pengalaman mereka dan bagaimana alat ini akan membantu mereka, "Para mama dianggap tidak mengerti jika para bapak mengadakan pesta. Mereka selalu yang tentukan kapan adanya pesta. Jika ada kalender ini, para mama akan bisa mengatakan 'lihat kalender itu, sekarang bulan ini, warnanya menunjukkan ini'. Dengan begitu para mama bisa mengatakan pada para bapak agar kita berhemat, kita tidak boleh lapar."

Rencananya, kalender yang masing-masing mereka buat, akan ditempel di ruang keluarga bahkan ada yang berencana akan dipasang di ruang depan, supaya seluruh anggota keluarga, baik suami, istri, dan anak untuk lebih peka dan terlatih mengatur dan mengambil keputusan dari alat ini. Dengan demikian, mereka optimistis musim lapar pada bulan Januari dan Februari dapat dihindari.

Diskusi kelompok $\mathrm{C}$ yang terdiri pada perangkat desa dan tokoh adat memunculkan istilah mengenai selisih musim. Hal ini karena faktor terbatasnya pengetahuan mengenai waktu dalam pertanian. Persiapan tanam ini disebut dengan "jemput musim", karena pemahaman yang berbeda maka ada selisih (salah) musim sehingga ada perbedaan waktu menanam antara petani satu dengan yang lainnya. Ketidakkompakan ini terjadi karena sebagian orang di desa tersebut tidak memahami musim. Keadaan tidak paham musim ini dalam bahasa Wewewa disebut ata dapadena rapa. Pendidikan mengenai musim seolah tidak dimiliki oleh banyak orang. Padahal, mengenal musim sangat penting untuk bercocok tanam. Dalam keadaan ata dapadena rapa, warga yang terlambat bercocok tanam akan dibantu oleh mereka yang sudah bekerja di ladang.

Mereka menyatakan, bahwa kalender musim dapat dijadikan alat membantu untuk latihan melihat musim tanam dan panen mereka. Dengan demikian, selisih musim dapat berkurang. Kelompok C mengatakan setelah pesta sering kali timbul masalah baru karena banyak orang justru akan kekurangan bahan pangan dan juga uang. Selain itu, beberapa tanaman seperti sorghum juga sebenarnya tidak dapat terlalu bisa berkembang di daerah Wewewa yang basah. Warga Laga Lete mengandalkan padi sebagai bahan pangan utama mereka. Katanya, kalender musim ini dapat mereka jadikan peringatan agar orang tidak selisih musim dan agar orang berhemat serta dapat bersepakat mengatur masa-masa pesta. 
Humanika Vol. 28 no 1 Copyright @2021

\section{Available online di http://ejournal.undip.ac.id/index.php/humanika}

Seperti tampak dari paparan pada

FGD ke FGD di atas, mentransformasikan tradisi lisan ke dalam tulisan menggunakan mnemonic device kalender musim meskipun merupakan proses yang kompleks, dapat dimudahkan dan mungkin dikerjakan. Peraga visual itu mengasyikkan. Orang dewasa terlihat senang memegang, menggerak-gerakan dan memainkannya. Anak kecil pun tertarik ikut memainkannya. Pelan tapi pasti, orang mulai meneliti dan bertanya-tanya. Selama ini banyak petani yang pemenuhan kebutuhan pangannya berbenturan dengan kepentingan adat. Mereka merasakannya, tetapi mereka kesulitan berargumen secara sederhana untuk keluar dari benturan kepentingan itu. Keniscayaan putaran musim, bila berbenturan dengan tuntutan sosial dari adat, diabaikan. Sebab musabab pengapesan atau kesialan akibat benturan itu sering kali tidak lagi dipersoalkan. Itu dianggap salah kaprah biasa dan bahkan, bila terpaksa menjelaskannya, maka penjelasan sering-sering diserahkan begitu saja pada kelemahan dan ketidakberdayaan perorangan dalam mengantisipasi irama musim. Mempertanyakannya pun orang tak kuasa, sehingga benturan itu merumit seperti benang kusut, sulit diurai. Pengenalan kalender musim yang visual, sederhana dan mudah dioperasikan (users friendly) ini, telah menampakkan harapan bahwa kerumitan itu dapat dimediasikan hingga dirembug (dimusyawarahkan). Oleh karena itu benang kusut itu sedikit demi sedikit dapat terurai. Para petani dapat secara terorganisir mengingat atau menemukenali kembali cara perhitungan musim beserta tanda-tanda alaminya di Sumba Barat Daya.

Kalender musim yang digunakan sebagai bahan acuan berkedaulatan pangan ini telah dirancang untuk membantu orang yang berbeda-beda bisa beradaptasi, menyelaraskan hidup sehari- hari dan kegiatan-kegiatan adatnya sesuai dengan perubahan musim, iklim dan bumi. Bentuk kalender yang berisi lapisan lingkaran-lingkaran, yang luwes dapat digerakkan secara independen, terbukti dapat mengakomodir hakikat polisemi dari suatu gejala alam/musim. Alat peraga ini memungkinkan orang yang berbeda-beda latar belakang budaya identitas sosialnya memusyawarahkan perbedaan tafsir mereka atas gerak alam. la memudahkan orang secara arif memberi konteks sosialekonomi atas perubahan lingkungan alaminya. Alat peraga itu memberi inspirasi peserta FGD mencari jalan keluar dari krisis perubahan kebudayaan, yang telah mengancam kedaulatan pangannya. Saat diminta untuk mengungkapkan bagaimana pengalaman mereka ketika berlatih menggunakan alat ini, para peserta diskusi menyatakan bahwa mereka menjadi sadar selama ini perhitungan dan strategi bercocok tanam serta kegiatan adat mereka banyak sekali yang tidak tepat. Kalender musim ini memberikan pertanyaan kritis pada diri mereka sendiri sehingga para peserta dapat insaf dan lebih percaya diri menghadapi perubahan musim. Alat tersebut juga menjadi acuan literasi, yang memediasi atau memberi semacam budi bahasa atas pengalaman batin, suka-duka bercocok tanam pangan yang belum terperikan baik secara lisan maupun tertulis. Para peserta FGD terbantu di Sumba Barat Daya telah terbantu dapat melakukan penerapan taktik dan strategi kedaulatan pangan.

Dari proses FGD di berbagai kesempatan, penelitian ini antara lain menemukan fakta berikut: warga di Desa Laga Lete, Kecamatan Wewewa Barat, misalnya, menyebutkan bahwa waktu tanam yang meleset dapat menyebabkan kekurangan pangan. Kalender musim menjadi petunjuk untuk masyarakat sehingga selisih musim dapat dihindari dan panenan terjamin. Setiap kelompok 
masyarakat yang terlibat dalam FGD berpendapat, bahwa alat ini akan membantu mereka mengetahui kapan musim tanam yang tepat. Kalender ini juga memberikan peringatan (dengan perbedaan warna) mengenai ancaman bulan-bulan kelaparan, maka pengaturan atau manajemen ketersediaan pangan menjadi prioritas. Warga di Desa Pero Batang, Kecamatan Kodi misalnya kemudian menyatakan bahwa selain beras, sebaiknya petani juga menanam kacangkacangan sebagai campuran beras. Dengan demikian, mereka dapat menghemat penggunaan beras. Penggunaan kalender musim ini telah membantu warga Desa Laga Lete, Desa Pero Batang, Desa Waikaninyo, pemerintah, dan para aktivis kedaulatan pangan menjadi paham, bahwa mereka harus berhati-hati dalam mengatur konsumsi pangan. Mereka juga lebih peka dengan perhitungan waktu tanam agar tidak mengalami salah musim, karena konsumsi bahan pangan di Sumba Barat Daya terkadang terakselerasi oleh tradisi pesta, Mereka kemudian juga merasa perlu menggeser waktu pestapesta adat mereka sesuai dengan kondisi pangannya. Mereka menemukan mana pesta yang harus dan tidak harus dilakukan.

Pengalaman para peneliti dan penulis artikel ini sepanjang proses penelitian menyatakan, bahwa kalender musim seperti yang dipaparkan di sini, sungguh-sungguh dapat diterapkan secara partisipatoris, inklusif, emansipatif dan demokratik. Kami mengalami betapa peserta yang berbeda-beda, baik yang telah mendapatkan pendidikan literasi maupun yang belum dapat bersama-sama aktif dapat mengisi dengan tulisan, gambar, maupun simbol yang sesaat mereka sepakati. Memang benar terdapat individu yang cepat memahami dan ada pula yang belum memahami sepenuhnya penggunaan kalender itu. Mereka yang cepat memahami, seperti para kepala desa dan tokoh masyarakat, bahkan dengan cepat memproyeksikan bahwa peraga ini dapat dipakai untuk musyawarah desa dalam membuat peraturan desa. Terbukti ada seorang calon kepala desa yang sengaja mengundang para peneliti untuk datang ke desanya dan menyelenggarakan FGD. Penerapan kalender musim ini bersama para sarjana pendamping desa. Kepala Desa Laga Lete menyatakan, "Ini termasuk kalender kerja. Boleh saya katakan perencanaan kerja keluarga. Sehingga, salah satu permasalahan kita di sini kan tidak ada kalender, to? Dengan tidak adanya kalender, kita kerja me(rabaraba). Kita kerja menurut kita, apa adanya. Hanya turun ramai. Tapi, bagaimana mengatur secara baik? Mengatur jadwal secara baik? Ini kelemahan kita selama ini." Para perempuan peserta FGD secara umum merasa terbantu dengan kalender peraga ini untuk sewaktu-waktu berargumen dengan suaminya yang cenderung mau menang sendiri dalam mengatur pengeluaran sumber pangan rumah tangga untuk kedde (pertukaran pemberian), untuk menjamin status sosial dalam sistem pertukaran yang terpicu pesta-pesta adat. Salah satu peserta FGD perempuan mengatakan: "Kalender ini mengingatkan dan bisa untuk menjelaskan (suami) kalau ada warna merah di sini 'Pak, kita harus persiapan sehingga nanti di bulan satu dan bulan dua kita tidak boleh lapar dan kita punya makan'." Dengan demikian alat peraga ini juga berfungsi untuk mengembangkan semangat emansipatif. Bagi para peneliti sendiri proses panjang, pelibatan sebanyak mungkin pihak untuk terus mengupayakan efikasi dari kalender musim ini, sungguh membesarkan hati. Seorang anggota peneliti berujar: "Saya baru ikut penelitian seperti ini, senang sekali melihat hasil kerja 
Available online di http://ejournal.undip.ac.id/index.php/humanika

(akademik) kita dapat langsung dipraktikkan penggunanya."

\section{Simpulan}

Penelitian ini menawarkan alternatif melalui mnemonic device berupa kalender musim dalam mengatasi persoalan selisih musim yang menyebabkan peristiwa kelaparan di Sumba Barat Daya. Kalender ini merupakan alat bantu atau media penghubung untuk menemukenali hubungan tradisi budaya lisan dengan tradisi budaya yang serba tertulis dan sistematis. Alat ini dengan mudah dapat digunakan oleh siapa saja lintas gender, usia, dan kelas untuk evaluasi ketepatan hubungan antara budidaya pangan, putaran musim alami dan daur sosial kultural. Kemudian dengan alat ini, warga masyarakat dapat memitigasi risiko selisih musim hingga krisis pangan secara terorganisir. Selain itu dengan menggunakan alat ini, musyawarah penyusunan peraturan desa dapat lebih terbuka bagi seluruh lapisan warga masyarakat untuk mengatur pilihan produk dan budidaya bahan pangan. Meliputi skala dan saat kegiatan-kegiatan sosial budaya, adat istiadat dapat diselaraskan dengan tata musim alami yang terpetakan dalam kalender musim. Pendekatan dan metode partisipatoris penting digunakan dalam penelitian-penelitian sosial-budaya. Penerapan kalender musim secara partisipatoris di Kabupaten Sumba Barat Daya, terbukti dapat menjadi media konsientisasi (peng-insafan) bagi warga (khususnya peserta diskusi) untuk membebaskan diri dari ketidakadilan yang menyebabkan kelaparan dan kemiskinan. Bagaimanapun, konsientisasi merupakan modal dasar untuk mewujudkan perubahan-perubahan sosial-budaya, yaitu Sumba yang berdaulat pangan.
Pada dasarnya kalender musim diciptakan sesederhana mungkin dengan lapisan-lapisan elemen yang terbatas. Lapisan elemen-elemen alat ini masih terbatas pada sistem alami waktu, curah hujan, jenis budidaya tanaman bahan pangan pokok dan komplementer, serta kegiatan upacara atau pesta adat. Dengan demikian, para peserta atau calon pengguna alat ini tidak kehilangan kesempatan memberikan konteks bagi perubahan lingkungan ketika mengoperasikan alat ini. Oleh karena itu, alat ini dapat terus dikembangkan sesuai dengan kebutuhan setempat dalam merumuskan taktik dan strategi menghadapi tanda-tanda alam yang terus berubah agar orang dapat membebaskan diri dari ancaman kelaparan dan berdaulat pangan.

\section{Ucapan Terima Kasih}

Artikel ini adalah luaran tambahan dari kegiatan publikasi penelitian yang didanai oleh Kementerian Riset dan Teknologi melalui skema pendanaan Hibah Penelitian Terapan Unggulan Perguruan Tinggi Tahun 2021, dan dengan dukungan fasilitasi dari Pusat Studi Asia Pasifik Universitas Gadjah Mada.

Para penulis mengucapkan terima kasih pada lembaga-lembaga yang ikut serta mendukung proses penelitian yaitu Bappelitbangda Kabupaten Sumba Barat Daya, Rumah Budaya Sumba, Yayasan Donders dan para mahasiswa Sumba yang ada di Yogyakarta yang telah membantu kami mengenal lebih mendalam budaya Tanah Humba. Penghargaan juga kami sampaikan kepada para informan. Terima kasih atas ketulusan para informan dan partisipan workshop yang tidak dapat kami sebutkan satu persatu. 


\section{Referensi}

Campesina, European Coordination Via. 2018. Food Sovereignty Now!: A Guide to Food Sovereignty. https://viacampesina.org/en/wpcontent/uploads/sites/2/2018/02/Fo od-Sovereignty-A-guide-Low-ResVresion.pdf

Daldjoeni, N. (1984). 3. Pranatamangsa, the Javanese agricultural calendar its bioclimatological and sociocultural function in developing rural life. In The Environmentalist (Vol. 4, pp. 1518). https://doi.org/10.1016/s02511088(84)90172-4

Gunawan. (2017). Anut Grubyuk: RamaiRamai Petani Gunungkidul Menghadapi Proyek Penanaman Jarak Pagar [Universitas Gadjah Mada].

http://etd.repository.ugm.ac.id/pene litian/detail/113589

Kemmis, S. dan McTaggart, R. (2005) "Participatory Action Research: Communicative Action and the Public Sphere". In: Denzin, N. and Lincoln, Y., Eds., The Sage Handbook of Qualitative Research, 3rd Edition, Sage, Thousand Oaks, 559-603.

Kimura, A. H. (2013). Hidden Hunger: Gender and the Politics of Smarter Foods. Cornell University Press.

Laksono, P. M. (2017). "The Adat Contributions for the Villages to Develop Independently: Cases from the Kei Islands, Southeast Maluku Regency". Humaniora, 28(3), 254-264
Laksono, P.M. (2018). "Pelatihan dan Pembelajaran Metode Riset Aksi Partisipatoris Untuk Pemajuan Kebudayaan." Bakti Budaya, 131-142. Lappé, F. M., Collins, J., \& Rosset, P. (1997). World Hunger: 12 Myths. Earthscan.

Levi-Strauss, C. (1963). Totemism (Translated by Rodney Needham). Beacon Press. Boston.

Pimbert, M.P. (2008). Towards Food Sovereignty: Reclaiming Autonomous Food

Systems.https://www.researchgate.n et/publication/242513559_Towards_ Food_Sovereignty_Reclaiming_Auton omous_Food_Syste

Rosset, P. (2011). "Food Sovereignty and Alternative Paradigms to Confront Land Grabbing and the Food and Climate Crises". In Development (Vol. 54, Issue 1, pp. 21-30). https://doi.org/10.1057/dev.2010.10 2

Siegel, James T. (1993). Solo in the New Order: Language and Hierarchy in an Indonesian City. Princeton University Press.

Turner, Victor. (1969). The Ritual Process: Structure and Anti- Structure. Chicago: Aldine.

UU No. 18 Tahun 2012 tentang Pangan [JDIH BPK RI]. (n.d.). Retrieved January 29, 2021, from https://peraturan.bpk.go.id/Home/D etails/39100 